\title{
CONCEPTUAL APPROACH TO INTRODUCE AN INTEGRATED MODEL IMPROVING SMES E-BUSINESS TECHNOLOGIES
}

\author{
Melina Neykova ${ }^{1}$, Radoslav Miltchev ${ }^{2}$ \\ ${ }^{1}$ Ph.D. Chief Assist. Prof. University of Forestry, Sofia, Bulgaria, mneykova@ltu.bg \\ ${ }^{2}$ Ph.D. Assoc.Prof. University of Forestry, Sofia, Bulgaria, rmiltchev@ltu.bg
}

Received 0509 2019, Accepted 31092019

Small and medium-sized enterprises (SMEs) represent the dominant form of business organization in the economic system globally and play important roles in the economic development and increased competitiveness of the economy in the European Union (EU). The presented article analyzes the state and existing specific problems that have been observed in the existing practices related to the functioning and maintenance of the specialized information and communication systems and e-business technologies of the studied group of Bulgarian small and medium-sized industrial enterprises. The basic instrument for collecting the empirical data in the present study was a questionnaire survey conducted at 70 Bulgarian enterprises. How to implement appropriate technological solutions through which to overcome existing problems and to provide strategic advantages for the surveyed organizations in conducting e-business? As a result of identified shortcomings, obstacles and necessities, the main purpose of this study is to develop and present an integrated model for introduction of technological solutions aimed to improve the efficiency of automated and virtualised business activities in Internet, extranet and intranet environments. The developed model is based on specific information and communication technologies and contemporary good practices and aims to improve the e-business system in the long term, which in turn will lead to the increased sustainability and competitiveness of organizations in the economic market.

Key words: small and medium-sized enterprises (SMEs), information and communication technologies (ICT), e-business.

JEL Codes: D80, L80, L84, L86, O10.

\section{Introduction}

The global network is being used more and more actively as a tool for advertising the services and products offered by enterprises (Turban, 2017; Varbanov, 2014). It is a mandatory aspect in transforming a traditional business into an electronic one (Barfield, 2003; Li, 2006; Combe, 2006). So, the managers of the enterprises that are seeking to expand the market and increase their competitiveness are faced with the decision of not whether it is time for such a transformation, but how to do it in the best possible way (Gloor, 2012).

Copyright (C) 2019 The Authors. Published by Vytautas Magnus University. This is an open-access article distributed under the terms of the Creative Commons Attribution-NonCommercial 4.0 (CC BY-NC 4.0) license, which permits unrestricted use, distribution, and reproduction in any medium, provided the original author and source are credited. The material cannot be used for commercial purposes. 
At the same time, the issues related to the processes of storing, preserving and guaranteeing the corporate information flow are closely related to the digitization of information in modern business activities (Schmidt, 2015). Losing access to the growing volume of data that are available only in digital form can have serious consequences for the business activity and for the employees, partners, and users who are directly related to them (in this sense, the destruction, deletion, leakage or other mishandling of confidential data related to bank accounts, credit cards, agreements, specific technologies, know-how, etc.) (Salmela, 2007; Bulgurcu, 2010; Singhal, 2011). In addition, insufficient control over the processing of information assets may allow unreliable information to get into the data feeds and lead to the deterioration of the quality and integrity of confidential data. Moreover, unauthorized access to the information resources (intrusion by unauthorized persons) and the acquisition of key data from competitive structures can lead to lost business profits and competitive advantages. So, the cost of underestimating the information security policy and the lack of a strategy to ensure the security of e-business information can be extremely high for organizations and business entities.

The process of selecting and implementing a comprehensive e-business strategy and closely related information security policies and standards in organizations requires knowledge of modern measures and innovative technologies that can effectively provide secure, uninterrupted access to systems and information resources of organizations and mechanisms for preserving the confidentiality, integrity and accessibility of data. Therefore, along with the imposition of organizational, administrative, legal, moral, and ethical norms, this article focuses on that the corporate managers and ICT specialists must necessarily improve their information security strategy with the increasing variety of hardware and software technical tools and technologies that are available on the market. In this sense, given the development of today's information society, a more competent, more knowledgeable team with high digital skills (Mladenova, 2019) has a higher rate of success and contributes to enhancing the organization's competitiveness and image with contractors, partners and consumers. Therefore, the main thesis discussed in this article is that to achieve productive development and high competitiveness organizations must implement a comprehensive innovative strategy for the constant search for and implementation of new and more efficient technologies for upgrading, improving and addressing possible weaknesses, threats and vulnerabilities in the corporate information infrastructure. At the same time the structural differences among the national innovation systems and the competitive advantages that characterize each innovation approach (Alnafrah, 2019) also have an impact and need to be considered.

The clarification of the theoretical foundations for the positions of various Bulgarian and foreign authors on e-business and its development on the basis of the introduction of innovations and possible concepts for advanced ICT (Chaffey, 2007; Bharati, 2010; Gloor, 2012; Varbanov, 2015; Turban, 2017) reveals the possibility of improving the operation of Bulgarian small and medium-sized enterprises (SMEs) and increasing their competitiveness. Milchev et al. (2013) indicates that the correct application and acceptance of e-business systems contribute to a shift in management 
thinking, as well as taking the necessary final decisions related to the introduction and development of e-business and ensuring its economic efficiency. Varbanov (2015) examines the main reasons, which determine the closer integration between the social media and business processes within companies. Ahmedova (2015) noted that the state should apply a systematic and unified methodology to help identify those particular SMEs that demonstrate potential in terms of some or all crucial factors for development and competitiveness.

Numerous comparative studies have been conducted in the field of the possibility of improving the operation of Bulgarian small and medium-sized enterprises (SMEs) and increasing their competitiveness. However, we did not find any comprehensive models or approaches which is aimed at a concrete practical solution and overcoming of the analyzed ICT problems so that to do not burden the budget of enterprises with additional ICT expenses and at the same time, these solutions must constitute a strategic means of gaining a competitive advantage over other companies in the market that operate in the same business domain and are forced to use typical ICT investments. In this regard, the main purpose of this article is to develop and present an integrated model for the introduction of technological solutions for improving the efficiency of automated and virtualised business activities in Internet, extranet and intranet environments. The developed model is based on specific information and communication technologies and contemporary good practices and aims to improve the e-business system in the long term, which in turn will lead to the increased sustainability and competitiveness of organizations in the economic market.

\section{Materials and methods}

The basic instrument for collecting the empirical data in the present study was a survey conducted independently at 70 Bulgarian enterprises (261 participants). The questionnaire includes 60 questions in order to get a better insight into the status of ICT systems and the e-business measures applied by the surveyed group of Bulgarian SMEs. In view of the advantages of the modern web-based surveys, one part of the questionnaires were filled out on paper, whereas the remaining ones were conducted online by filling in a specially developed online form. The distribution of respondents according to their positions in enterprises is shown in Figure 1.

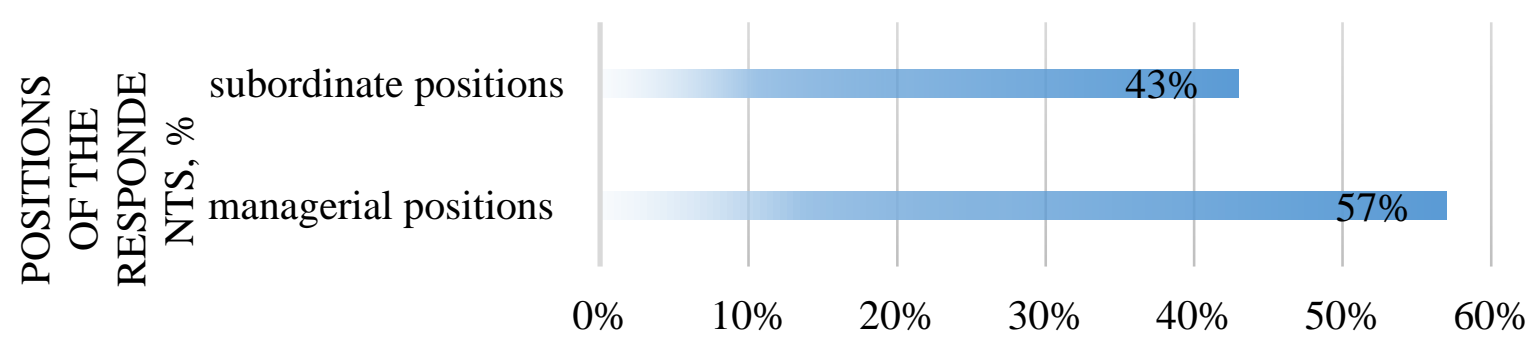

Figure 1. Distribution of respondents according to their positions in enterprises, percentage 
The affiliation of the respondents according to the number of personnel is as follows: $33 \%$ of respondents work in micro-enterprises; $33 \%$ belong to small enterprises, and the remaining $24 \%$ belong to the group of medium-sized enterprises (Fig. 2). A total of $90 \%$ of the respondents are classified as belonging to SMEs but only $10 \%$ of the respondents work in large enterprises (with over 250 employees, according to the Law for SMEs). The group of the large participating companies is not a subject of the present study but has been investigated as a necessary party for comparison and in order to make a clearer assessment of the state of SMEs in the country. In this regard, according to the data of the National Statistical Institute (NSI), among the number of enterprises in the non-financial sector in Bulgaria predominates micro, small and medium-sized enterprises (99.8\%) (NSI, official website), and in addition the observed tendency in the total number of SMEs is growing, in contrast to the sector of large enterprises, with microenterprises being the most numerous (SBA Fact Sheet; 2018). According to the distribution of the respondents by the sphere of activity of the organizations - working in the services sector are twice as many (67\%) than those working in the manufacturing sector (28\%) and rural business (5\%).
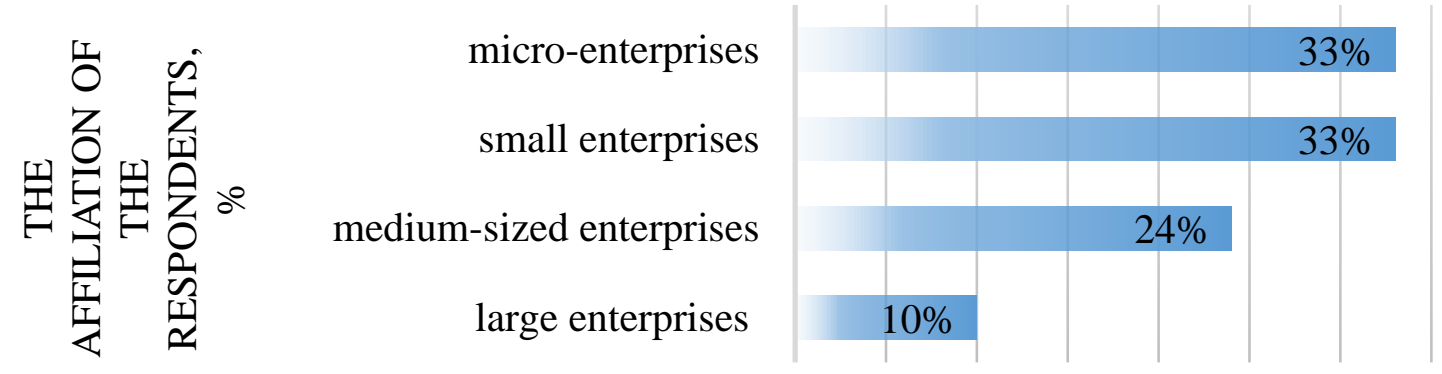

$\begin{array}{lllllllll}0 \% & 5 \% & 10 \% & 15 \% & 20 \% & 25 \% & 30 \% & 35 \%\end{array}$

Figure 2. The affiliation of the respondents to the group of SMEs, percentage

According to the data obtained from the survey, the predominant form of business ownership of the studied organizations is private $-68 \% ; 23 \%$ of the respondents are classified as working in state organizations, while only $9 \%$ work in mixed enterprises. It must be taken into account that the role and importance of this factor for the level and quality of ICT is associated with budgetary possibilities and restrictions, especially in state enterprises.

\section{Results and discussion}

\subsection{Results of conducted research}

The investigation conducted by the authors was able to establish specific problems have been observed in the existing practices related to the operation and maintenance of the specialized information and communication systems and ebusiness technologies (Neykova; Miltchev, 2017) the more important of which are presented below. 
In recent years, the introduction of ICT solutions is implemented more and more actively in Bulgarian SMEs which is due to the new managerial idea of achieving strategic advantage through ICT investments and their direct impact on improving the quality of automated business activity in enterprises. This assertion is supported by the results, obtained from the survey on the issue of to what extent the development of the business activity of organizations depends on ICT. From the received information almost all of the respondents (97\%) think that no business activity in their organization can be implemented without ICT, which means that the surveyed enterprises must not only maintain their ICT, but also introduce advanced solutions to improve their overall strategy for information support.

The availability of computers (especially a new generation of computers) and a local computer network in the organizations is the basic condition for the construction of an ICT infrastructure as well as for a variety of e-business purposes. The survey data confirm that regardless of the size of the enterprises, almost all of the studied organizations have developed a computer network which they use in their business activity. The information clearly indicates that the practice in various sized companies is to use a different number of computers. So, while in micro-enterprises the predominant number is less than 5 computers, in small enterprises the predominant number is more than 5 and up to $10 \mathrm{PCs}$. And the majority of medium-sized and large enterprises tend to use more than 10 computers in their business. This circumstance is directly related to the scope of activity of enterprises and their financial capabilities, and the need to have skilled IT specialists and an ICT maintenance unit should be taken into consideration.

A compulsory aspect of the management of IC systems is the use of various software products in the business activities of organizations and the data received from the survey indicate that the surveyed organizations use the following software products:

- office applications (word processing systems and spreadsheet programs, applications for reading an email, browsing the Internet, etc.) $-42 \%$ of respondents;

- accounting software $-30 \%$ of respondents;

- programming software for human resources management $-16 \%$ of respondents;

- specialized business programs that are related to the subject of activity of the organization $-11 \%$ of respondents;

- other programs $-1 \%$ of respondents.

In this context, it is appropriate in different organizations to have a separate structural unit which is responsible for the maintenance of computer systems and software. But the results of the conducted survey show that the majority of respondents $-70 \%$ - confirmed that such a structural unit is not available in their organizations and these results testify to the existence of risks to the information security and confidential data of the organizations and the possible loss of business benefits. The 
prevailing number of replied respondents work in micro and small enterprises (89\%). In this sense the result can be explained by the insufficient financial resources which are necessary for setting up a department, responsible for the maintenance of computer systems and software as well as the impossibility to employ qualified ICT specialists, who are responsible for the timely implementation of effective technological innovations that ensure the confidentiality, integrity and accessibility to corporate information assets and resources. Furthermore, despite the fact that according to $97 \%$ of respondents the business activities of their organization are directly dependent on ICT resources, but the majority of the surveyed companies (62\%) do not have ICT staff or, in a greater number of cases, it is insufficient and consists of 1 to 3 people.

In recent years, a growth trend in the use of the Internet is observed across Bulgarian businesses. These data are also confirmed by the results, obtained in this survey, which show that the rate of Internet connectivity in the monitored enterprises is very high and almost all respondents (97\%) confirm the presence of an Internet connection that is used for various business activities (Fig. 3).

The low share of enterprises that implement e-commerce makes an impression in the obtained results, which can be interpreted as a serious indicator of the need for innovative solutions for the development of e-business systems in Bulgarian enterprises.

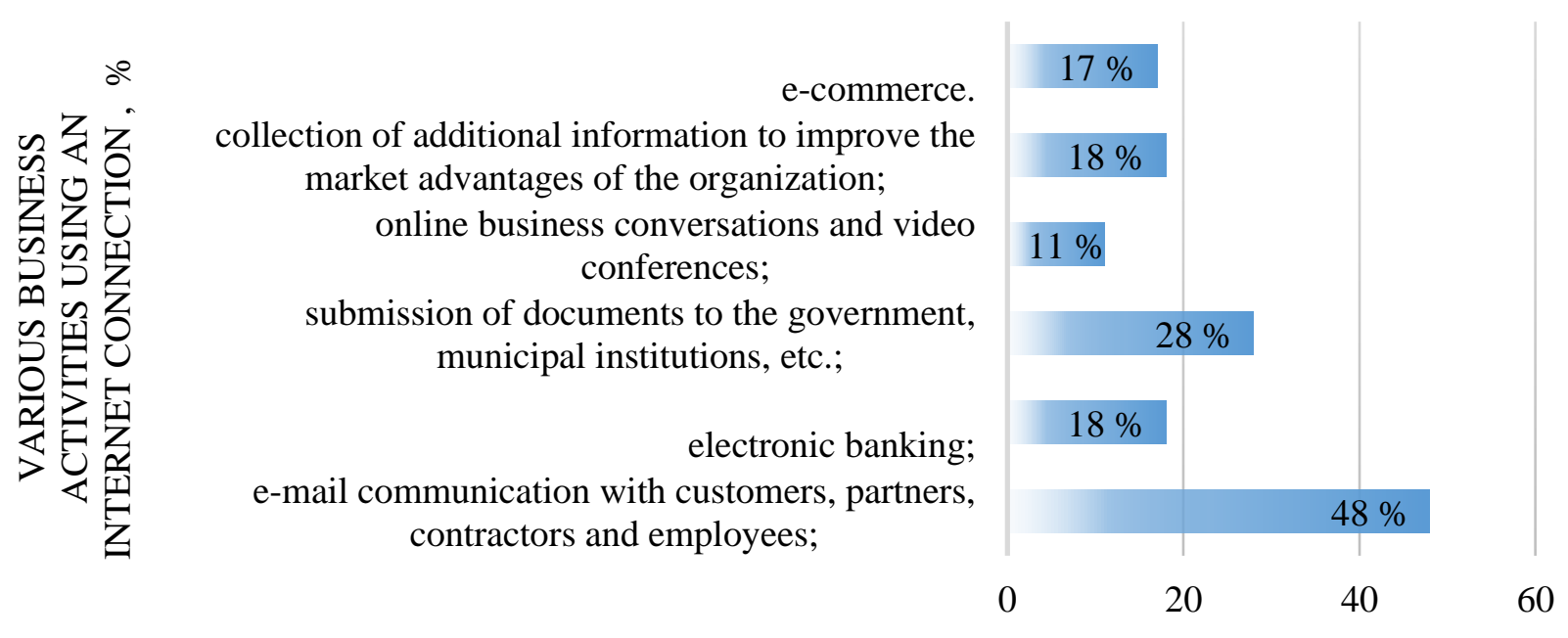

Figure 3. Various business activities using an Internet connection, percentage

The development of e-business activity of the organizations should be presented on the Web via an attractive website. It should be as up-to-date as possible, with rich content and an integrated Internet concept. In this way, the organization will send its fundamental marketing message and build its reputation among customers, partners and counterparties on an international scale. The enterprises participating in this study make no exception, and almost all of them have built a website (92 \%). The data, obtained from the inquiry on the influence that the company website has on the development and competitiveness of the business activity of surveyed organizations, 
indicate that almost all respondents $(93 \%)$ reported that the availability of an electronic website affects the activity of enterprises. According to the majority of respondents (53 $\%)$, this influence is great and it has led to a sharp increase in the development and competitiveness of the implemented business activity. In addition, in answer to the question of whether the competitors of the studied organizations have a website, most of the respondents ( $72 \%$ ) gave a definite positive response, which in turn is another confirmation that any enterprise that wants to strengthen its presence in the market and expand the scope of its business activities, must make a name for itself in the online space.

The dynamic generation of various information technologies and devices and the ever more active implementation of e-business require the need to ensure processes that are related to the confidentiality and integrity of information assets of the organizations and the availability and authentication of the authenticity of employees, partners and customers. The conducted study revealed problems with the undervaluation of e-business systems, which are exacerbated when considering the state of information security in the surveyed enterprises. In this sense, more than half of the respondents $(55 \%)$ are not aware of and cannot answer the question of whether analyses were conducted to assess the state of information and communication support and the level of information security in the organizations.

The indicated problem could be linked with the inability to take relevant measures and approaches for the protection of and access to information assets due to financial difficulties or lack of ICT skills and qualified personnel. It follows from the above that the majority of the surveyed organizations are not capable of performing periodic innovations of their ICT systems, including of introducing and implementing active measures (through appropriate technological innovation) that help to increase IC and prevent critical risks and threats to the confidential information resources of the organization. In addition, most respondents (67\%) are of the absolute opinion that no properly documented information security policy exists, that taking into account the affiliation of respondents according to the size of the companies shows that this problem is concentrated mainly in micro and small enterprises (85\%). This, in turn, can be interpreted as a serious risk and a threat to the confidential information assets and resources of the surveyed organizations. Thus, the e-business system can be seriously threatened, and a situation can occur where competitive organizations and business entities can acquire key data and important information.

Based on the information, obtained in the survey on the type of methods that are used to identify the staff when accessing information assets in the organizations, a username and password or personal identification number are indicated in the first place as the predominant method of identification (66\%) (Fig. 4). The second most common methods of identification, used by the surveyed enterprises, are the identifications performed by means of personalized cards $(21 \%)$ or electronic cards $(9$ $\%)$. Only $2 \%$ of all surveyed respondents confirmed that their organizations use fingerprint identification. Unfortunately, the biometric technologies that provide a high 
degree of precise identification (Edgington, 2007) are not used by the surveyed group of organizations. Thus, taking into account the global data and studies related to breaches in security of the information resources of organizations reveals disturbing facts about the existing risks in the corporate information system, including essential disadvantages of the approaches based on the possession of physical objects and those based on the knowledge of certain information, as they can be forgotten, lost, provided to somebody else, or even stolen by ill-intentioned people.

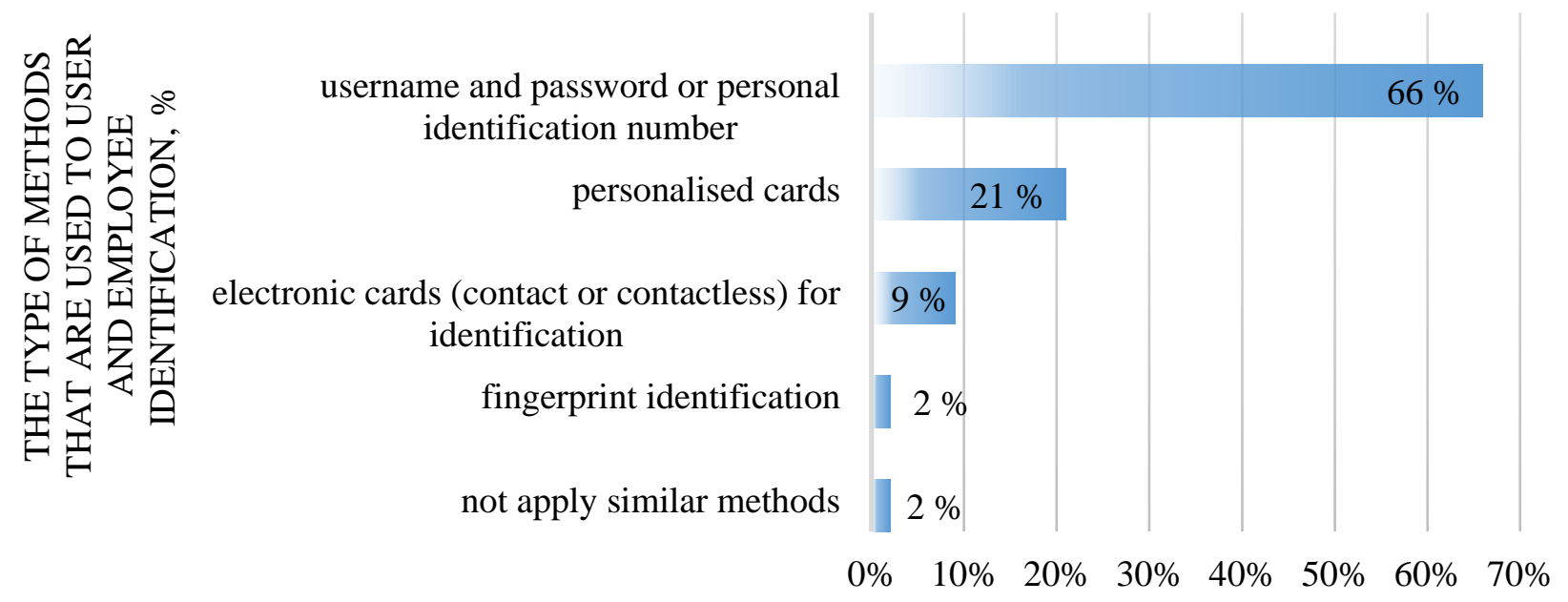

Figure 4. The type of methods that are used to user and employee identification, percentage

These arguments are supported by results from the survey question about the existing disadvantages of the methods of identification of employees when accessing the information resources and assets of the organization as:

- the high cost of resources and devices $-29 \%$;

- low security and accuracy in the identification of the individual (the means may be provided to or stolen by another user or employee) - 32 $\%$;

- low resistance when attempting forgery $-21 \%$;

- low speed in processing and storing information $-4 \%$;

- difficulty to be used by consumers or employees $-14 \%$.

In this regard, the study makes an inquiry on whether the organizations applied methods to increase the control over employee access to information resources and assets. The results again showed a poorly localized attention and insufficiently active measures in this direction, in consequence of which problems can occur in the business activities of organizations and confidential data and business benefits can be lost. In this sense, $85 \%$ of respondents agree that their enterprises do not use methods for increasing the access control of the employees. At the same time, $70 \%$ of the respondents find that there is a need to further increase the level of security when employees access the information resources and assets in the organization. Moreover, 
$60 \%$ of them are employees in managerial positions, which fact emphasizes the depth of the assessment and the urgent necessity of the introduction of actual measures.

When providing access to the network information systems and e-business assets of the organizations in continuous mode $24 / 7$ to employees, partners, contractors and customers, a server system must be ensured, which requires increased use of electricity, cooling as per the parameters of the machine and permanent (software and hardware) maintenance. In the conducted research, more than half of the respondents (72\%) confirmed that their organizations have a server/server. But when examining the storage requirements for the server/servers, it becomes clear that: $20 \%$ of the respondents claim that the servers used by their enterprises are stored by external organizations; $28 \%$ confirm that the servers are stored in the same way as all other computers in the organization, without meeting the requirements that are needed to overcome the premature aging of the equipment and a possible failure to operate 24/7. Such negative influences could lead to missed business opportunities and loss of clients and partners for the organizations.

In addition, more than $75 \%$ of respondents have indicated that their enterprises do not have an uninterruptible power system (UPS - Uninterruptible Power Supply) during the operation of the server/servers, which is a prerequisite for the loss of key and critical data and information in case of unexpected disruptions of electricity or electric shocks.

The survey reveals the fact that almost all respondents $(94 \%)$ claim that the monitored enterprises use devices for the climatization of the work environment (temperature and humidity), which are air conditioning (61\%), central climatization $(11 \%)$ and ventilation (22\%). However, almost half of them (49\%) are convinced that it is necessary to improve the level of control of the temperature and humidity on the premises where information and communication devices are stored.

It is clear from the data in the conducted study that most investigated businesses (95\%) do not use spare devices for monitoring the ICT environment (a specialized electronic device for precise air-conditioning and control of the temperature and humidity). Obviously, this is one of the serious shortcomings in terms of the exploitation of the ICT devices and server machines, because such innovative technologies could facilitate the performance of remote monitoring of communication premises in organizations and warn of critical conditions of the surrounding environment, which may adversely affect the entire information resource of the organization and could result in the loss not only of critical data, but also of expensive information and communication equipment.

In conclusion, almost all the surveyed organizations have set up an Internet connection and an electronic website, which are some of the basic steps to build and implement a successful e-business. But it should be noted, that these resources should be available 24 hours a day, 7 days a week, and 365 days a year, and this is the reason why necessary ICT equipment and qualified support for continuous operating mode must be ensured. However, the majority of the surveyed organizations do not have an 
ICT department and enough staff to maintain computer systems and software, which necessitates the use of third-party services. And this is a deficiency that shows insufficient assessment of the importance of the management of the e-business ICT system.

It was also found that in the surveyed enterprises there is a favorable environment for the introduction of innovations in the field of information systems (IS) and ICT and the professionals working at the enterprise display a positive attitude and willingness to innovate. In addition, a large number of the respondents (53\%) think that the management of the organization they are working at is planning to introduce technological innovations in the field of ICT. Most of the respondents (62\%) confirm that the companies they are working at are ready and willing to take specific measures to improve their ICT. And a large number of surveyed enterprises which are reluctant to implement actual measures to improve security at the moment belong to the group of micro and small enterprises which are faced with a shortage of financial resources, high competition in the market and often a lack of highly qualified personnel. As a result, the introduction of innovations and the existing information and communication problems have the lowest priority. Thus, in the end, the surveyed SMEs are at a disadvantage compared to their competition and the large enterprises on the market.

\subsection{A conceptual approach for the stepwise introduction of an integrated model}

As a result of the performed analysis and the established necessary measures that should be taken by the surveyed SMEs, the present conceptual approach has been developed and proposed for the introduction of an integrated e-business model that will enhance the efficiency of automated and virtualized business activities. This approach was developed in such a way as not to burden surveyed SMEs too heavily with additional costs and investments. For this purpose, the proposed model offers accessible solutions and FOSS, which are in line with the current trends in the application of e-business systems typical of the business practices of large organizations and businesses, as well as opportunities for re-use and utilization of the available equipment and extra economic gain, regardless of its depreciation and aging. The solutions based on the proposed approach are appropriate both for organizations lacking the necessary ICT staff and for organizations with insufficient capital to upgrade ICT resources. The proposed approach can also be seen as a competitive advantage over other companies in the market that are operating in the same sphere of business and are forced to make investments for ICT innovations typical of their business domain.

The structure of the integrated model is based on key technological innovations. Figure 5 represents the logical framework of the conceptual approach for a phased-in introduction of the proposed solutions. Depending on the problems and weaknesses identified in the practices implemented by the surveyed organizations, management teams of specialists adopt appropriate management decisions and express their 
readiness to innovate through a process of phased-in introduction of the proposed concept.

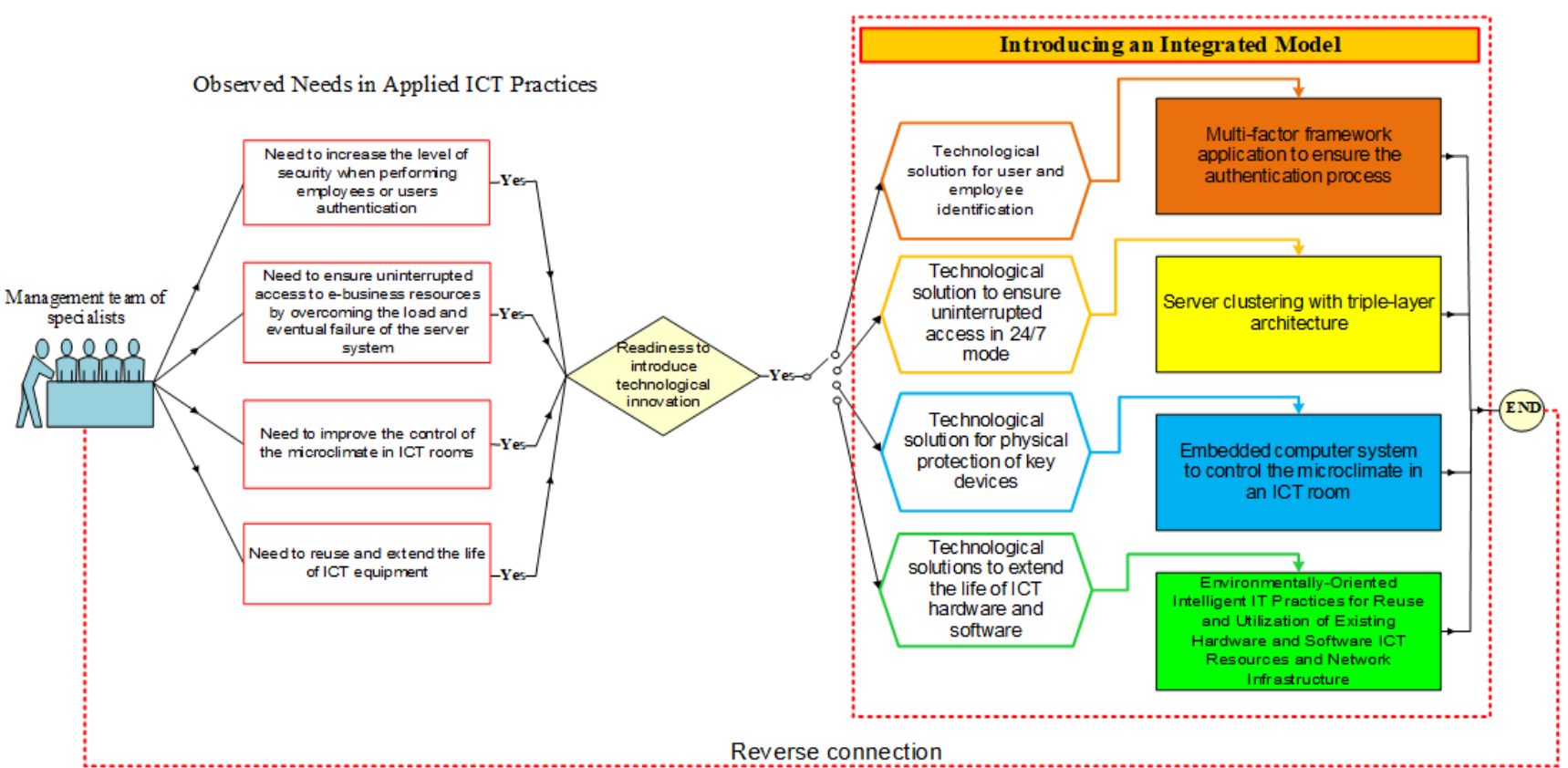

Figure 5. A conceptual approach for the stepwise introduction of an integrated model

Technological solution for user and employee identification. The majority of the surveyed enterprises need to further increase the level of security when employees and users of the organization access information resources and assets. In this regard, a large number of the surveyed enterprises are ready and willing to take specific measures to improve information security. Moreover, the survey shows that at present in the surveyed organizations there is insufficient action to implement methods to increase access control as well as insufficient recognition of the importance of doing this. It has also been established that the predominant means of staff identification used by organizations is the provision of a username and password in order to gain access, but identification systems with a much higher degree of protection, such as biometric technologies, are hardly ever applied.

Based on the conducted studies it can be concluded that the best practices for increasing security and access control demonstrate the need to use two or more ways of identification in the process of authentication. In response, the presented integrated model proposes a technological solution based on the authors' developed multifactorial framework application (Miltchev; Neykova, 2014) which is achieved as a result of the combination of different methods of authentication, depending on the goals adopted in the security policy of organizations or business entities.

During the first stage of user authentication a conventional recognition technique is applied through a username and password, which are suitably encrypted in order to increase the level of security. The second level of authentication is performed using a smart card and a smart card reader. The development is consistent 
with the popular device models that have been applied to other activities in the organizations. In order to provide a higher level of authentication of a user's identity biometric authentication is applied, which is implemented by fingerprint and finger vein scanning devices (Fig. 6). The proposed biometric identification is a more reliable method for authentication of the individual than those presented in the first two stages, because conducted studies in the organization have shown that it is possible to provide the passwords, as well as smart cards to third parties, especially in the event of an emergency, most often related to the absence of the employees and the need for their tasks to be performed (Hitachi Security Solutions, 2014). The used fingerprint or finger vein patterns are a unique personality trait that cannot be replaced.

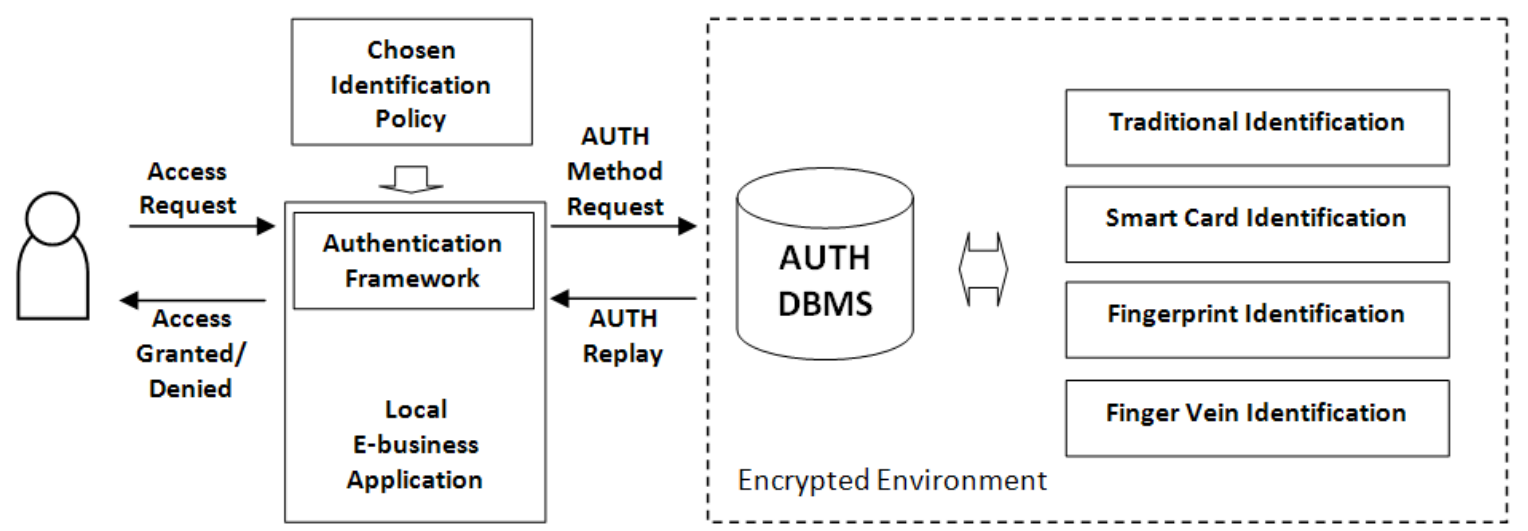

Figura 6. Structure of the developed test environment for multifactor application

Technological solution to ensure uninterrupted access in 24/7 mode. Almost all of the surveyed SMEs have a built-in network infrastructure, namely computer and server devices and a built-in computer network, an Internet connection and a variety of software products, as well as a functional website. In addition, the study found that many of the businesses (especially micro and small ones) have their servers stored by external organizations. Unfortunately, many of the companies in Bulgaria, which fall within the category of small and medium-sized enterprises, do not have enough qualified ICT personnel to be able to implement innovative solutions ensuring reliable and permanent access to online e-business resources. Hence, the presented integrated model proposes a solution developed on the basis of a key technological innovation that ensures the uninterrupted access to the enterprise's IS in a 24/7 mode ( 24 hours, 7 days a day, 365 days a year), namely server clustering with triple-layer architecture (Miltchev; Neykova, 2015), providing the following opportunities:

-easing server support by dividing individual physical machines into many virtual ones, each of which having its own operating environment and work applications;

- using physical and virtualised servers simultaneously;

- using the available hardware and software so as to optimize space for storing data;

-promoting energy savings; 
-reducing the load on the hardware;

-increasing the performance of the server system;

-increasing the efficiency of the management of information and communication resources by managing several different operating systems simultaneously from a single computer machine;

-working with a large number of e-business applications that can be deployed on a smaller number of physical machines;

-optimizing financial investment through the use of open source solutions and proper configuration of existing hardware and software resources.

Since the present study was aimed at ensuring the reliability and security of online e-business resources of small and medium-sized companies, which usually do not feature sufficient finances to invest in expensive equipment, an approach for the implementation of the indicated scheme was sought. The approach was focused on the use of existing computer equipment in the office of the company which is generally used by the employees as part of their daily work, or the reuse of machines as well as computer equipment which are no longer actively used. In this sence the studied solution is part of environmentally-oriented intelligent IT practices as it contributes to reducing the harmful impacts on the environment by doing away with outdated computer office equipment.

A series of experiments were conducted for the purposes of this study, which have been organized into two main groups. The business part of the triple-layer architecture of the e-business platform of the travel company is installed on the group of developed cluster nodes (Node 1, Node 2, ..., Node N). In the present case both the possibilities to access static content and the possibilities to access dynamic content have been investigated and for this purpose a content management system which is installed on the nodes has been tested, where in this specific case Joomla version 3.3 was used. The database which is used by the content management system is installed and configured on a separate server. For the purposes of implementing the proposed approach a server for balancing the requests of online service users was installed and configured. At the same time different balancing test modes were developed, including equal load balancing (suitable in the cases where the nodes of the cluster used have similar hardware features) and unequal load balancing (suitable in cases where the cluster is constructed using heterogeneous computer systems with different hardware parameters).

The proposed solution was tested in a real working environment. The balancing server is located in the Demilitarized Zone of the organization, which is accessible to external requests from customers, partners and contractors of the organization or company. The cluster of nodes and the server that stores the database were placed in a special network segment of the internal corporate network of the organization, whose purpose was to simulate the workstations that are used by the staff of the organization or business entity, which are practically located inside the intranet network. Such an approach is suitable from the viewpoint of protecting information assets. And at the 
same time standardized network devices are used that are suitable for performing office activities (router and switches). The scheme in Figure 7 shows the physical topology of the environment in which the proposed solution was tested, as well as the information flows that are generated as a result of the internal and external traffic when handling requests for access to an online e-business resource of the relevant organization or business entity. In the present case the requests from external users are directed towards a balancing server which manages traffic and redirects it to the nodes of the internal network that form the cluster. The nodes send back a response which gives access to the resources of the tourist company - home page, page for making online reservations, e-catalog, etc. that are forwarded from the balancing server to the external users who have made the relevant request for access to the e-business resource.

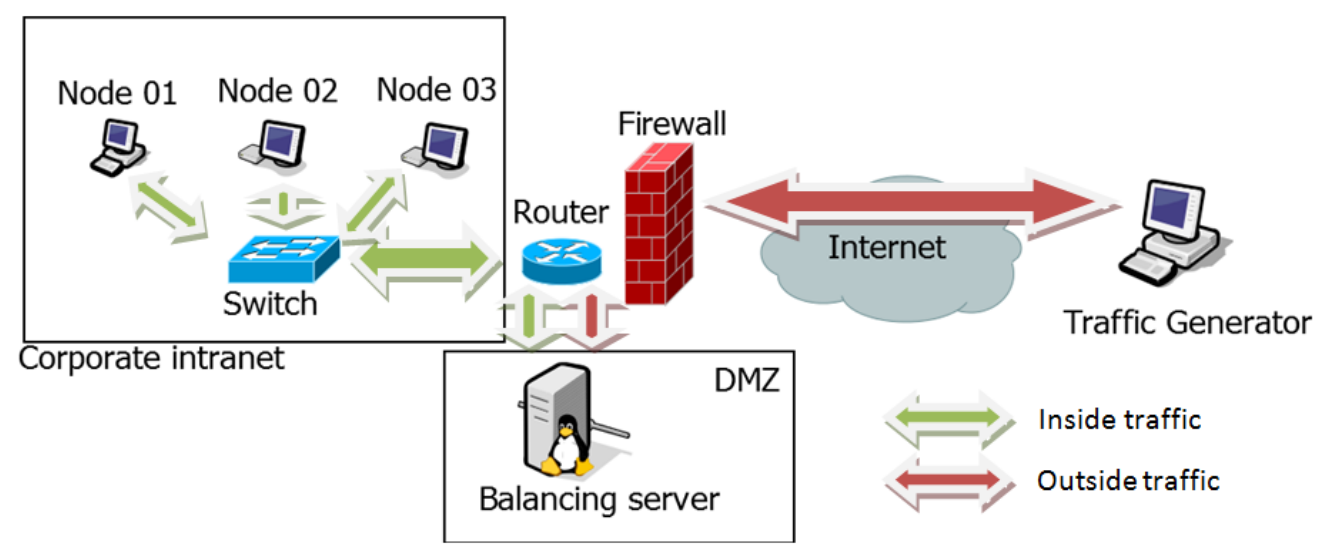

Figure 7. Physical topology of the test environment

Technological solution for physical protection of key devices. The results from the survey showed that it is necessary to improve the level of control over the microclimate in the rooms where the information and communication devices are stored. The surveyed organizations hardly ever use specialized additional devices for precise air conditioning and temperature and humidity control, which may negatively affect both the operation of the servers and the entire information resource of the organization. In response to that, the integrated model proposes a solution based on a technological innovation for the physical protection of key e-business devices, namely a embedded computer system for controlling the microclimate in a computer communication/server room with the possibility of remote monitoring through different types of networks, including through the networks of telecommunication operators whose main objective is to monitor the ICT environment so that it is stable and controllable (control over temperature and humidity), and avoid the premature aging of the equipment as well as any potential failures of the systems to operate in a 24/7 mode (Miltchev; Neykova, 2013).

An integrated system based on the Arduino Uno hardware solution was used to perform the tasks in the integrated model, which also enables the management and 
control of different types of networks by adding additional modules with standardized integration. For the purposes of this study, an embedded system was designed to connect to IEEE 802.3 networks, which is in line with the results of a survey on the data medium used, so that the device itself can be easily located in server or communication room and integrate with existing infrastructure. To the working model is fitted a sensor for measuring the temperature and humidity of the environment. The software required to install the microcontroller is implemented using the Arduino programming language based on the use of Wiring and a graphical development environment based on the use of Processing. The development of application software to solve the problems of building a system for controlling and managing the climate parameters of server and communication rooms was accomplished through the use of an Arduino platform environment. The software provided includes sensor management and network communication of the device. For the purpose of storing measurement data, a three-layer web-based application was developed and standardized. It based on the use of PHP and MySQL, which allows the creation of an appropriate frontend environment for monitoring and tuning the device. The performed tests have shown that the selected implementation of the proposed embedded computing systems provide the opportunity to effectively implement technological innovations for creating stand-alone devices or for incorporating them into more sophisticated control systems and at the same time to do not burden the budget of enterprises with additional ICT expenses

Technological solution to extend the life of ICT. Taking into account the recent economic crisis in the country, which affected all sectors of the economy, and its negative impact on the groups of surveyed SMEs, as well as their unfavorable position compared to market competitors and the rapid growth and development of large enterprises, it is reasonable to seek solutions which do not burden the budget of enterprises with additional ICT expenses. Such approaches can be considered to constitute a strategic means of gaining a competitive advantage over other companies in the market that operate in the same business domain and are forced to use typical ICT investments. For this purpose, the proposed integrated model offers affordable and open-source solutions as well as opportunities for reusing existing techniques that are suitable for organizations that do not have the necessary ICT staff. In this sense, the Integrated Model enables the implementation of solutions developed on the basis of technological innovations to extend the life-time of material and technical support in organizations, namely eco-oriented intelligent IT practices for reuse and utilization of existing hardware and software ICT resources and network infrastructures available in enterprises. The approach chosen allows the use of hardware and software products with low resource consumption, such as operating systems operating without a graphical interface, but providing the necessary support for the proper maintenance and use of the organization's e-business system. At the same time, the application of the integrated model also contributes to the reduction of the harmful effects on the environment by reducing the disposal of outdated computer and office equipment. 
Such an approach is also directly related to the WEEE Directive (Waste electrical and electronic equipment) to reduce the amount of waste electrical and electronic equipment as one of the fastest growing waste streams currently in Europe (Eurostat, Waste statistics).

\section{Conclusions}

As a result of the performed analysis, in the present research a conceptual approach has been developed and proposed for the introduction of an integrated ebusiness model that enhances the efficiency of automated and virtualised business activities. The development of the presented concept support the management of enterprises and their specialists, especially micro and small enterprises, which the analysis proved that in most of the cases underestimate the role of ICT due to a shortage of financial resources and other external and internal factors.

The conducted analysis showed that the majority of surveyed enterprises are ready and willing to take specific measures to increase the level of security when employees and users of the organization access information resources and assets. In this regard the presented integrated model proposes a technological solution for identifying users and employees based on the authors' developed multifactorial framework application providing the process of user authentication in organizations and controlling access to information resources at four levels. The developed application is consistent with the requirements of the organization to provide opportunities for operation and reconciliation with existing systems and resources, at minimum cost of investment.

At present the existing tendency is towards the massive use of websites and the increasing importance of e-resources as a tool that brings additional business benefits to the organizations and business entities. In this regard almost all of the surveyed SMEs have a built-in network infrastructure, namely computer and server devices and a built-in computer network, an Internet connection and a variety of software products, as well as a functional website. This determines the necessity of ensuring a secure and reliable $24 / 7$ access to the resources provided online. Therefore the presented integrated model proposes server clustering with triple layer architecture.

The results from the survey showed that it is necessary to improve the level of control over the microclimate in the rooms where the information and communication devices are stored. In response to that, the integrated model proposes a solution based on embedded computer system for controlling the microclimate with the possibility of remote monitoring through different types of networks, including through the networks of telecommunication operators whose main objective is to monitor the ICT environment so that it is stable and controllable (control over temperature and humidity), and avoid the premature aging of the equipment as well as any potential failures of the systems to operate in a 24/7 mode. 
Taking into account the recent economic crisis in the country, which affected all sectors of the economy, and its negative impact on the groups of surveyed SMEs, as well as their unfavorable position compared to market competitors and the rapid growth and development of large enterprises, the proposed integrated model presents technological solutions which aims to do not burden the budget of enterprises with additional ICT expenses. Such approaches can be considered to constitute a strategic means of gaining a competitive advantage over other companies in the market that operate in the same business domain and are forced to use typical ICT investments. For this purpose, the authors offers affordable and open-source solutions as well as opportunities for reusing existing techniques that are suitable for organizations that do not have the necessary ICT staff. The introduction of the presented integrated solutions also aims to reduce the need for outsourcing services that support e-business activities in SMEs, which is linked to additional financial costs for enterprises and a possible risk and threat to the organization's ICT security.

The introduction of the proposed integrated model takes steps to bring about sustainable use of computer equipment by organizations and it can stimulate the processes of innovation in Bulgarian enterprises if they review and adopt in a timely manner the proposed innovative solutions and key technologies for the development of electronic business and trade in Bulgaria as they are priority areas for development under European and national strategies for the periods before and after 2016-2020.

Acknowledgement: The present study was initiated and implemented with the support of the National Science Program "Young Scientists and Postdoctoral Students". We express our gratitude for the concern for the young researchers, scientists and professors of Bulgaria.

\section{References}

Alnafrah, I., Zeno, B. (2019). A new comparative model for national innovation systems based on machine learning classification techniques //Innovation and Development. Routledge doi. 10.1080/2157930X.2018.1564124.

Ahmedova, S. (2015). Factors for Increasing the Competitiveness of Small and MediumSized Enterprises (SMEs) in Bulgaria // Procedia - Social and Behavioral Sciences. Volume 195, 3 Pages 1104-1112.

Barfield, C., Heiduk, G., Welfens, P. (2003). Internet, Economic Growth and Globalization: Perspectives on the New Economy in Europe, Japan and the USA. Berlin, Heideberg: SpringerVerlag, doi: 10.1007/978-3-540-24761-6.

Bharati, P., Lee, I., Chaudhury, A. (2010). Global Perspectives on Small and Medium Enterprises and Strategic Information Systems: International Approaches // Business Science Reference, USA.

Bulgurcu, B., Hasan, C., Izak, B. (2010). Information security policy compliance: an empirical study of rationality-based beliefs and information security awareness // Society for Information Management and the Management Information Systems Research Center Minneapolis, 


\section{Conceptual Approach to Introduce an Integrated Model Improving SMEs E-Business Technologies. Melina Neykova, Radoslav Miltchev}

MN, USA, Volume 34, Issue 3, p. 523-548.

Chaffey, D. (2007). E-Business and E-Commerce Management: Strategy. Implementation and Practice. Pearson Education Limited. England.

Combe, C. (2006). Introduction to E-Business. Routledge, Butterworth-Heinemann.

Edgington, B. (2007). Your quest for the ideal biometric: is it in vain? Introducing Hitachi's Finger Vein Technology // A White Paper. Hitachi Europe Limited, 9. http://www.hitachi.eu/veinid/ documents/veinidwhitepaper.pdf

Eurostat (2019). Waste statistics - electrical and electronic equipment. http://ec.europa.eu/eurostat/statistics-explained/index.php/Waste_statistics_-

_electrical_and_electronic_equipment)[2019 06 10]

Gloor, P. (2012). Making the e-Business Transformation. London: Springer-Verlag, p. 179. doi:10.1007/978-1-4471-0757-6.

Hitachi Security Solutions: Hitachi ICT Solutions (2014). Finger Vein Biometric Systems. Retrieved. http://www.hitachi.com.sg/ict-solutions/solutions/fingerVein.html [2019 06 10]

Law for SMEs in Bulgaria, Prom. SG. 84, (1999). Final. Am. SG. 82 of 2009, Art. 3.

Li, F. (2006). What is e-business?: How the Internet Transforms Organizations, United States, Wiley-Blackwell.

Miltchev, R., Neykova, M. (2014). Development and Investigation of an Authentication Framework Application for Incorporation into Local E-Business Applications // Economy and Management, 2, p. 90 - 96.

Miltchev, R., Neykova, M. (2015). The Impact of Technological Innovations to The Sustainability of the E-Business Systems of Organizations Operating in the Tourism Sector. // Proceedings of 3rd International Scientific Conference Tourism in Southern and Eastern Europe, p. 223-233.

Miltchev, R., Neykova, M. (2013). Main trends in the development and use of embedded computing management systems // Management and Sustainable Development, 4, p. 142 - 147.

Milchev, G., Milchev, R. (2013). Contemporary trends in the e-business systems in the enterprises of mining and manufacturing // Journal of UCTM, 2013, p.12-18.

Mladenova M. (2019). Impact of information and communication technologies on business places Part 1: Development of the concept of digital competence. European frameworks related to digital competency. Intel Entrans, (In Bulgarian).

National Statistical Institute. Republic of Bulgaria // Non-financial Enterprises. http://www.nsi.bg/en/content/8035/non-financial-enterprises [2019 06 10]

National Statistical Institute. Republic of Bulgaria. Business Demography. http://www.nsi.bg/en/content/13218/business-demography [2019 06 10]

Neykova, M., Miltchev, R. (2017). The State of Applied Information and Communication Technologies and E-Business Practices in Bulgarian Small and Medium-Sized Enterprises. Eureka: Social and Humanities, Estonia, pp. 3. DOI: 10.21303/2504-5571.2017.00267.

Salmela, H. (2007). Analysing business losses caused by information systems risk: a business process analysis approach // Journal of Information Technology 23(3), p. 185-202. doi:10.1057/palgrave.jit.2000122 [2019 06 10]

Schmidt, R., Zimmermann, A., Möhring, M., Nurcan, S., Keller, B., Bär, F. (2015). Digitization - perspectives for conceptualization. In: Celesti, A., Leitner, P. (eds.) ESOCC Workshops 2015. CCIS, vol. 567, pp. 263-275. Springer, Heidelberg (2016). doi:10.1007/978-3319-33313-7_20[201906 10]

Singhal, A., Ou, X. (2011). Security Risk Analysis of Enterprise Networks Using Probabilistic Attack Graphs. Nat. Inst. Sci. Technol., Gaithersburg, MD, USA, Nat. Inst. Sci. 
Technol. Interagency Report 7788.

Small Business Act - SBA Fact Sheet - European Commission. (2018). Bulgaria.

Turban, E., Outland, J., King, D., Lee, J., Liang, T., Turban, D. (2017). Electronic Commerce 2018: A Managerial and Social Networks Perspective. Springer Texts in Business and Economics. Springer International Publishing AG, Switzerland, p.7. DOI: 10.1007/978-3-319-58715-8. [2019 $0610]$.

Varbanov, R. (2015). The Potential of Social Media for the Business of Companies. Economic Academy D. A. Tsenov. 25/2015, Issue No: 3, p. 5. ISSN 0861-6604.

Varbanov, R., Shishmanov, K. (2014). The New Generation Electronic Business and Electronic Payment Systems, Economic Academy D. A. Tsenov.

\title{
KONCEPTUALUS POŽIŪRIS İ INTEGRUOTĄ SMULKIOJO IR VIDUTINIO VERSLO İMONIŲ E-VERSLO MODELI
}

\author{
Melina Neykova ${ }^{1}$, Radoslav Miltchev ${ }^{2}$ \\ ${ }^{1,2}$ Mišku universitetas, Bulgaria
}

Gauta 201909 05, priimta 20190931

Mažos ir vidutinės įmonės yra dominuojanti verslo organizavimo forma ir vaidina svarbų vaidmenį plètojant ekonomiką ir didinant ekonomikos konkurencingumą Europos Sajungoje (ES). Straipsnyje analizuojama šio verslo vystymosi būkle ir egzistuojančios specifinès praktinès problemos susijusiojs su specializuotų informacinių ir ryšių sistemų bei elektroninio verslo technologijų veikimu ir priežiūra tiriamoje Bulgarijos mažų ir vidutinių pramonès įmonių grupèje. Pagrindinè šio tyrimo empirinių duomenų rinkimo priemonè buvo anketinè apklausa, atlikta 70 Bulgarijos įmonių. Tyrimo klausias - kaip igyvendinti tinkamus technologinius sprendimus, leidžiančius įveikti esamas problemas ir suteikti strateginius pranašumus tiriamoms organizacijoms vykdant elektroninị verslą? Atsižvelgiant ị nustatytus trūkumus, kliūtis ir būtinybes, pagrindinis šio tyrimo tikslas yra sukurti ir pristatyti integruotą technologinių sprendimų diegimo modelị, skirtą pagerinti automatizuotos ir virtualizuotos verslo veiklos efektyvumą interneto, ekstraneto ir intraneto aplinkose. Sukurtas modelis yra pagrịstas specifinėmis informacinèmis ir ryšių technologijomis bei šiuolaikine geraja patirtimi, kuria siekiama patobulinti e. Verslo sistemą ilguoju laikotarpiu, o tai savo ruožtu padidins organizacijų tvarumą ir konkurencingumą ekonominèje rinkoje.

Raktiniai žodžiai: mažos ir vidutinès įmonès, informacinès ir ryšiu technologijos, elektroninis verslas.

JEL kodai: D80, L80, L84, L86, O10. 